\title{
封管燃焼法による有機硫黄のサブミリグラム定量
}

\author{
穂積啓一郎 ${ }^{*}$, 佐藤 綾子 ${ }^{* *}$, 秋元 直茂 ${ }^{\circledR * * *}$
}

\section{Submilligram determination of organic sulfur using sealed tube combustion method}

$$
\text { Keiichiro Hozumi }^{*} \text {, Ayako SATOH }{ }^{* *} \text { and Naoshige Aкıмото }{ }^{* * *}
$$

\footnotetext{
${ }^{*}$ Kyoto Pharmaceutical University, 5, Misasagi-Nakauchi-cho, Yamashina-ku, Kyoto 607-8414

${ }^{* *}$ Faculty of Pharmaceutical Sciences, Tohoku University, Aramaki-aza-Aoba, Aoba-ku, Sendai 980-8578

${ }^{* * *}$ Faculty of Pharmaceutical Sciences, Kyoto University, 46-29, Yoshida-Shimoadachi-cho, Sakyo-ku, Kyoto 606-8304
}

(Received 12 December 1997, Accepted 11 February 1998)

\begin{abstract}
The microdetermination of sulfur in organic materials is currently being carried out by a tube combustion or a flask-combustion method. However, either way is not fully reliable for the accurate determination of samples at $1 \mathrm{mg}$ or below. Some years ago, a sealed-tube combustion method was proposed for the submilligram determination of organic halogens, featuring the complete decomposition of samples with small volumes of pure oxygen and no contamination or loss of components during the process. An extension of the same technique has therefore been made for the determination of organic sulfur. A weighed sample and a small volume of oxygen are sealed off in a Pyrex glass tube (od., $10 \mathrm{~mm}$; id., $8 \mathrm{~mm} ; 1 ., 18 \mathrm{~cm}$ ) having a fine-tip end. The sealed tube is heated in a cylindrical furnace at $580^{\circ} \mathrm{C}$ for $20 \mathrm{~min}$ and drawn out for cooling. The tube is held vertically with the tip end down and is pressed to the bottom of a small beaker containing a $3 \% \mathrm{H}_{2} \mathrm{O}_{2}$ solution. The tip end is then broken and the solution slowly enters into the tube, raising the liquid level by $2 \sim 5 \mathrm{~cm}$. While the tube is left standing for 10 $\mathrm{min}$, the sulfur oxides in the gas phase are entirely absorbed in the liquid phase to be sulfate ion. The sulfate ion can be accurately titrated spectrophotometrically at a wavelength of $660 \mathrm{~nm}$ with $0.005 \mathrm{~mol} / 1 \mathrm{Ba}\left(\mathrm{ClO}_{4}\right)_{2}$ standard solution using carboxyarsenazo as an indicator. Thirty or more determinations per day are feasible if several sealed tubes in one lot are heated in the furnace.
\end{abstract}

Keywords : microdetermination of organic sulfur; sealed tube combustion method; spectrophotometric titration; microtitration of sulfate.

1 緒 言

有機試料中の硫黄の定量分析は医薬品, 食品, 生体試
料, ゴム, 石炭, 石油など応用対象が広く, 古くから分 析方法の研究, 改良が行われてきた. Carius の湿式分 解法 ${ }^{12)}$, Pregl の燃焼管法 ${ }^{113)}$ についで, 近年は

\footnotetext{
*京都薬科大学: 607-8414 京都府京都市山科区御陵中内町 5

** 東北大学薬学部: 980-8578 宮城県仙台市青葉区荒巻字青葉

*** 京都大学薬学部: 606-8304 京都府京都市左京区吉田下阿達町 46-29
} 
Schöniger の酸素フラスコ燃焼法 ${ }^{1) 4}$ が普及している. 又, クロマトグラフ的手法による $\mathrm{CHN}$ 分析装置に $\mathrm{SO}_{2}$ の検 出を付加して硫黄の定量を可能にしたものもある ${ }^{5)}$.

酸素フラスコ燃焼法は, ガラス器具のみで分析が可能 である有利な条件を備えているが, 燃焼が瞬間的であ り, 沪紙の炎の中に試料が確実に包まれて分解したかど うかの不安がある. 又, 試料に比べ圧倒的に大量の沪紙 を燃焼させるのであるから, 洰紙中の硫黄分が空試験值 を高めないか検討が必要である.

一方穂積ら ${ }^{677)}$ は, 先に有機ハロゲンの超微量分析法 として乾式封管燃焼法を提案し, パイレックスガラスの 封管中に試料と酸素を閉じ込め, $580^{\circ} \mathrm{C}$ で 1 時間加熱し た．封管は一端を針状に引き伸ばしてあるので，燃焼後 吸収液を入れたビーカーに針端を突き立てて破壊する と，管内の陰圧のため吸収液が $2 \sim 5 \mathrm{~cm}$ 管内を上昇す る. 約 30 分放置した後, 管内に洗浄液を注入してハ口 ゲンイオンをビーカーに移し, 硝酸銀標準液で電位差滴 定した。本法は試料と数 $\mathrm{ml}$ の純酸素との反応であり, 閉鎖器中で時間をかけた燃焼が行われるため，成分の污 染や損失が全くない特長を有し，超微量分析に良い条件 を備えている.

この封管燃焼法は有機硫黄の定量にも応用可能と考え られるが，ハロゲンの場合と異なり，加熱された封管中 には $\mathrm{SO}_{2}$ と $\mathrm{SO}_{3}$ が共存し，これらを全部吸収液中に $\mathrm{SO}_{4}{ }^{2-}$ として溶解させることが必要となる．このため封 管寸法や操作方法に検討を加え, 試料量 $1 \sim 0.5 \mathrm{mg}$ のサ ブミリグラム領域で有機硫黄の定量を可能としたので報 告する.

\section{2 実験}

\section{$2 \cdot 1$ 試 薬}

$3 \%$ 過酸化水素水: $30 \%$ 過酸化水素水（東京化成製） を水で 10 倍に希釈.

$0.005 \mathrm{~mol} / 1$ 過塩素酸バリウム標準液: 約 $1.7 \mathrm{~g}$ の過塩 素酸バリウム (特級) を $200 \mathrm{ml}$ の水に溶解し, 更に水 を加えてメスフラスコで $1000 \mathrm{ml}$ とする. 硫酸ヒドラジ ン $(S=24.64 \%)$ (特級) 約 $1 \mathrm{mg}$ を 2 3 点精密に量り, 封管燃焼のプロセスを経た後, 滴定によって係数を求め, その平均值を算出する.

指示薬: カルボキシアルセナゾ（ドータイト試薬） 37 $\mathrm{mg}$ を $100 \mathrm{ml}$ の水に溶解する.

ジフェニルチオ尿素 $(S=14.04 \%)$, スルファニルア ミド $(S=18.62 \%)$ ，スルファチアゾール $(S=25.11 \%)$, $\mathrm{S}-$ ベンジルチウロニウムクロリド $(\mathrm{S}=15.82 \%)$, チオ 尿素 $(S=42.12 \%)$ : キシダ化学元素分析用標準試薬.

\section{$2 \cdot 2$ 器 材}

Pyrex 7740 ガラス管: 外径 $10 \mathrm{~mm}$, 内径 $8 \mathrm{~mm}$, 長さ $1.5 \mathrm{~m}$ の定尺のものを $25 \mathrm{~cm}$ に 6 等分した.

円筒型電気炉，白金スクープ，長柄ピンセット：既 報8)のものを用いた.

電子微量化学はかり：ザルトリウス製ウルトラミクロ はかり $\mathrm{S} 4$, 最大荷重 $4 \mathrm{~g}$, 電気的表示範囲 $120 \mathrm{mg}$, 最 小読み取り $0.0001 \mathrm{mg}$.

光度滴定装置：メトラーメモタイトレーターDL40に 光度滴定用アダプターDP660を取り付けた。このアダ プターは先端を試料液に挿入することにより，液中で $20 \mathrm{~mm}$ の光路長を形成し, $660 \mathrm{~nm}$ の光吸収を検出する. 滴定用の自動ビュレットは $5 \mathrm{ml}$ 容量で, 滴定值は $0.0001 \mathrm{ml}$ の単位でディジタル表示される.

\section{$2 \cdot 3$ ガラス封管の調製}

ガラス細工を伴う封管の作製法は既報 ${ }^{6) 7}$ に準じるが, 硫黄分析では外径 $10 \mathrm{~mm}$, 内径 $8 \mathrm{~mm}$ のものを用いる ので一層強いガス火炎が必要である。一端を酸素混合バ ーナーで強熱し，十分溶融して完全に管を閉じたものを 必要数準備する. 試料 $1 \sim 0.5 \mathrm{mg}$ を白金スクープを用い て精密に量り，長柄ピンセットに保持してガラス管の閉 端付近に落とす.

酸素ボンベから流量計を介して細いテフロン管に 20 $\mathrm{ml} / \mathrm{min}$ 前後を流し, 試料を入れたガラス管の中央まで 差し込んで 1〜2 分空気を追い出す.このあと酸素混合 バーナーで閉端から約 $18 \mathrm{~cm}$ ところを加熱し, 少し引 き伸ばした上, 同じ所を再び強熱して針のように引いて 閉じる. 出来上がった針端は少し横向きに曲げておくと あとで吸収液中で破壊しやすい.

\section{$2 \cdot 4$ 分析操作法}

試料を入れた封管は数本をまとめて $580^{\circ} \mathrm{C}$ の電気炬 に入れ, 燃焼させる. 約 20 分後封管を取り出し, 金属 製ラックに載せて放冷する. $100 \mathrm{ml}$ の滴定用ガラスカ ップに $3 \%$ 過酸化水素水 $5 \mathrm{ml}$ を入れ, 封管の針端をカ ップの底に突き立てると針端は破壊し, 吸収液は $2 \sim 5$ $\mathrm{cm}$ の高さまで封管内を上昇する. 各封管を別のカップ 中で同様に処理して約 10 分放置し, 封管内の硫黄酸化 物を全部硫酸イオンとして吸収液に溶解させる。

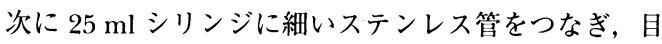
盛りいっぱいまで 2-プロパノールを充たした後，封管 の破壊口にステンレス管を扱入して噴射液流で管内を洗 い出す．洗液は全部ビーカー内に落とすよう留意する. 2-プロパノール $10 \mathrm{ml}$ を加え, 被滴定液の含水量を 
Table 1 Recovery of sulfur after different time of combustion

\begin{tabular}{lcccccc}
\hline \multicolumn{1}{c}{ Sample } & $\begin{array}{c}\text { Weight/ } \\
\mathrm{mg}\end{array}$ & $\begin{array}{c}\text { Combustion/ } \\
\mathrm{min}\end{array}$ & $\begin{array}{c}0.005 \mathrm{~mol} / \mathrm{l} \\
\left.\left[\mathrm{Ba}^{2+}\right] / \mathrm{ml}^{\mathrm{a}}\right)\end{array}$ & $\begin{array}{c}\text { Sulfur/ } \\
\mathrm{mg}\end{array}$ & $\begin{array}{c}\text { Result, } \\
\%\end{array}$ & $\begin{array}{c}\text { Dev., } \\
\%\end{array}$ \\
\hline Diphenylthiourea & 0.6384 & 5 & 0.6211 & 0.0896 & 14.08 & 0.04 \\
$(\mathrm{~S}=14.04 \%)$ & 0.6561 & 5 & 0.6400 & 0.0921 & 14.12 & 0.08 \\
& 0.6993 & 5 & 0.6800 & 0.0982 & 14.08 & 0.04 \\
& 0.8056 & 10 & 0.7751 & 0.1131 & 13.97 & -0.07 \\
& 0.8556 & 10 & 0.8247 & 0.1201 & 14.01 & -0.03 \\
Thiourea & 0.6150 & 10 & 0.6150 & 0.0890 & 14.03 & -0.01 \\
$(\mathrm{~S}=42.12 \%)$ & 0.7980 & 5 & 1.9123 & 0.3361 & 35.10 & -7.02 \\
& 0.6541 & 5 & 1.8704 & 0.2755 & 41.88 & -0.24 \\
& 0.7182 & 5 & 1.7113 & 0.3025 & 34.88 & -7.24 \\
& 0.6863 & 10 & 1.9650 & 0.2891 & 41.94 & -0.18 \\
& 0.6059 & 10 & 1.7536 & 0.2552 & 42.37 & 0.25 \\
\hline
\end{tabular}

a) A blank value of $0.020 \mathrm{ml}$ was subtracted before calculation of the result.

$15 \%$ 以下とし，これに指示薬 $0.5 \mathrm{ml}$ を加え， 0.005 $\mathrm{mol} / \mathrm{l}$ の過塩素酸バリウム標準液を用い, $660 \mathrm{~nm}$ で光 度滴定する.

\section{3 操作条件の設定}

\section{$3 \cdot 1$ 封管寸法}

試料は封管内の酸素のみで完全燃焼を達成しなければ ならないが，単純に有機物を $\mathrm{CO}_{2}$ と $\mathrm{H}_{2} \mathrm{O}$ に酸化するた めに必要な酸素体皘を求めると, 例えばステアリン酸 $\mathrm{C}_{18} \mathrm{H}_{36} \mathrm{O}_{2} （ M_{\mathrm{w}}=284.5 ）$ の場合, $36+18-2=52$ 個の酸 素原子を要求するので酸素分子は 26 モルとなる．ステ アリン酸 $1 \mathrm{mg}$ に対しては 0.091 ミリモルであるから, 酸素体積としては常圧で $2.05 \mathrm{ml}$ となる. 分子式の異な る化合物では $1 \mathrm{mg}$ に対応する酸素量も異なるが, ほと んどのものが $2 \mathrm{ml}$ 前後かそれ以下である.

有機ハロゲンの分析に用いた外径 $8 \mathrm{~mm}$, 内径 $6 \mathrm{~mm}$, 長さ $15 \mathrm{~cm}$ の封管は内容積が約 $4 \mathrm{ml}$ で, $1 \mathrm{mg}$ 以下の試 料に対しては化学量論の 2 倍あったことになる. 経験 的にハロゲン分析に関してはこの封管寸法で良い分析結 果が得られた。

しかし硫黄分析に同様の封管を用いると，しばしば著 しく低い分析結果が得られた。このことは気相中に

$$
\mathrm{SO}_{2}+1 / 2 \mathrm{O}_{2} \rightleftarrows \mathrm{SO}_{3}
$$

の平衡があり，試料の燃焼のために酸素を消費すると， 残留する酸素分圧が低下して平衡を十分右に傾け得ない 状況になり，封管の針端を吸収液の中で破壊して $\mathrm{H}_{2} \mathrm{O}_{2}$ を導入しても, 気相中の $\mathrm{SO}_{2}$ を待ち時間内に吸収でき
ないためと考えられる.そこで封管の外径を $10 \mathrm{~mm}$ ， 内径を $8 \mathrm{~mm}$ とし, 胴部の長さを $18 \mathrm{~cm}$ とすると酸素 量は約 $9 \mathrm{ml}$ となり, 後述のように吸収時間 10 分で定量 的な分析結果が得られた。

\section{$3 \cdot 2$ 燃焼及び吸収条件}

封管内の酸素量がハロゲン分析のときの 2 倍以上に なったので, 燃焼条件はハロゲン分析のときょり有利で ある. パイレックスガラスの軟化点の関係で燃燒温度は $580^{\circ} \mathrm{C}$ とするが, 燃焼時間については Table 1 のように 10 分でほぼ定量的な結果が得られた。他の数種の標準 試料についても同様であった．操作条件としては余裕を 見て 20 分とした。

一方硫黄分析では気相に $\mathrm{SO}_{2}$ を残留させているので, その吸収酸化のための $\mathrm{H}_{2} \mathrm{O}_{2}$ 濃度と吸収時間について検 討が必要である．酸素フラスコでは燃焼後吸収液を激し く振り混ぜ, 更に静置してからもフラスコ内部の広い面 積で燃燒気体と吸収液膜との接触ができるが, 封管法で は細長いガラス管の下部に上昇してきた吸収液との狭い 接触面のみであるから, あまり能率の良い状況ではな い. そこで残存する $\mathrm{SO}_{2}$ を酸化するための $\mathrm{H}_{2} \mathrm{O}_{2}$ の濃度 と必要な吸収時間について検討を行った。

まず吸収時間を 1 時間とし, ジフェニルチオ尿素及 び S-ベンジルチウロニウムクロリド 1 0.5 mg を燃焼 して, 吸収液の $\mathrm{H}_{2} \mathrm{O}_{2}$ 濃度と滴定值から吸収効果を調べ た。吸収液が水のみのときはいずれも理論值から 2 $3 \%$ 低い值が得られたが， $\mathrm{H}_{2} \mathrm{O}_{2}$ 濃度 $1 \%$ 以上で定量的 な結果が得られた。吸収時間を 30,10 分と短縮しても ほほ同じ結果が得られたので, 分析条件としては $\mathrm{H}_{2} \mathrm{O}_{2}$ 


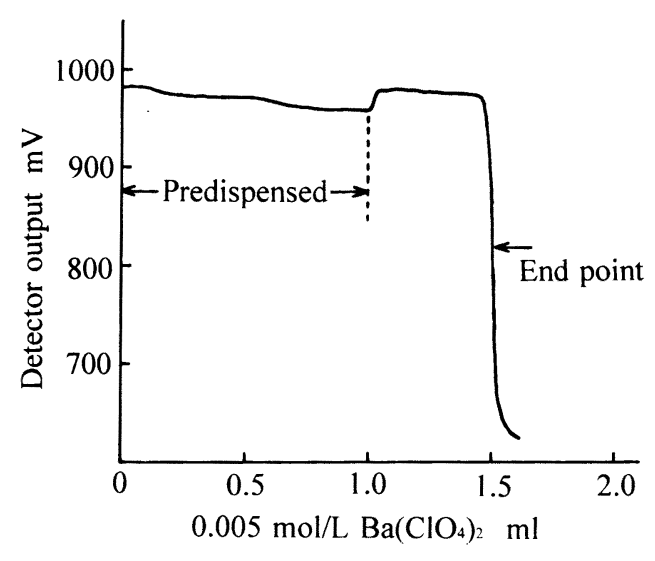

Fig. 1 Spectrophotometric titration of sulfate using carboxyarsenazo as an indicator

Sample: $1.5 \mathrm{ml}$ of $0.005 \mathrm{~mol} / 1 \mathrm{H}_{2} \mathrm{SO}_{4}$; Titrant: $0.005 \mathrm{~mol} / \mathrm{l} \mathrm{Ba}\left(\mathrm{ClO}_{4}\right)_{2}$; Wave length: $660 \mathrm{~nm}$; Delivery speed: $0.2 \mathrm{ml} / \mathrm{min}$

A $1.000 \mathrm{ml}$ of titrant was predispensed at high delivery speed. End point was electronically determined by max. change of output signal per unit increment.

3\%，吸収時間 10 分で良いと思われる.

\section{$3 \cdot 3$ 谪定条件}

$\mathrm{SO}_{4}{ }^{2-}$ の目視滴定用指示薬としてはトリン, アルセナ ゾ III"が㥶用されたが, 現在ではカルボキシアルセナ ゾ(0)が当量点における色の変化が比較的明りょうで, か つアルセナゾIII のような色の戻りがなくよく用いられ る。この試薬はヒ素を含むが, アルセナゾ III に比べ $1 / 2$ で, 滴定後の廃液処理の負担もそれだけ軽減され る.カルボキシアルセナゾを用いた目視滴定では赤紫色 から青紫色の変化で，正確な終点の認定には多少熟練を 要するが，単色光による光度滴定では当量点付近で Fig. 1 のように急しゅんな出力変化があり，最大変化点を終 点とする滴定值が再現性よく得られる。 なお本滴定例で は滴定值が大きいので $1 \mathrm{ml}$ まで滴定液を急速に注加し て時間を節隇した。

滴定装置に付属する光度滴定用アダプターはフォトダ イオードから発する 555 と $660 \mathrm{~nm}$ の 2 種類の光源が選 ベるが，カルボキシアルセナゾを指示薬としたときの当 量点前後における光量変化は $660 \mathrm{~nm}$ のほうが大きく, この波長バンドを使用した。

希薄な $\mathrm{SO}_{4}{ }^{2-}$ 溶液の沈殿滴定であるから, 沈殿の生 成速度が遅い可能性があり，そのときは滴定速度によっ て滴定終点の位置がずれることがありうる。これを検討
Table 2 Effect of delivery speed on end point determination

\begin{tabular}{ccc}
\hline $\begin{array}{c}\text { Delivery speed/ } \\
\mathrm{ml} \mathrm{min}^{-1}\end{array}$ & $\begin{array}{c}\text { Time until } \\
\text { end point }\end{array}$ & $\begin{array}{c}0.005 \mathrm{~mol} \mathrm{l}^{-1}\left[\mathrm{Ba}^{2+}\right] / \\
\mathrm{ml}\end{array}$ \\
\hline 0.200 & $2^{\prime} 9^{\prime \prime}$ & 0.5543 \\
0.100 & $4^{\prime} 8^{\prime \prime}$ & 0.5470 \\
0.075 & $6^{\prime} 30^{\prime \prime}$ & 0.5429 \\
0.050 & $8^{\prime} 39^{\prime \prime}$ & 0.5466 \\
0.040 & $13^{\prime} 0^{\prime \prime}$ & 0.5519 \\
0.030 & $17^{\prime} 18^{\prime \prime}$ & 0.5502 \\
\hline
\end{tabular}

Table 3 Relationship between quantity of sulfur and volume of titrant ${ }^{\dagger}$

\begin{tabular}{ccc}
\hline $\begin{array}{c}\text { Hydrazine sulfate/ } \\
\mathrm{mg}\end{array}$ & $\begin{array}{c}\text { Sulfur/ } \\
\mathrm{mg}\end{array}$ & $\begin{array}{c}0.005 \mathrm{~mol} \mathrm{l}^{-1}\left[\mathrm{Ba}^{2+}\right] / \\
\mathrm{ml}\end{array}$ \\
\hline 1.2090 & 0.2979 & 1.9992 \\
1.0386 & 0.2559 & 1.7257 \\
0.9367 & 0.2308 & 1.5586 \\
0.7520 & 0.1853 & 1.2490 \\
0.5325 & 0.1312 & 0.8997 \\
0.4099 & 0.1010 & 0.6888 \\
0.3945 & 0.0972 & 0.6702 \\
0.3377 & 0.0832 & 0.5812 \\
0.3320 & 0.0818 & 0.5703 \\
0.2654 & 0.0654 & 0.4576 \\
0.2520 & 0.0621 & 0.4363 \\
0.2094 & 0.0516 & 0.3625 \\
\hline
\end{tabular}

${ }^{\dagger}$ The data was transformed into linear regression expressed by the equation (1).

するために約 $0.005 \mathrm{~mol} / 1$ の硫酸を 10 倍に希釈し，そ の $5 \mathrm{ml}$ をデイスペンサーで正確に採り，滴定速度を変 えて $0.005 \mathrm{~mol} / 1 \mathrm{Ba}\left(\mathrm{ClO}_{4}\right)_{2}$ で繰り返し滴定した。滴定 值は約 $0.5 \mathrm{ml}$ と少ないが，これで実分析の滴定値 1 2 $\mathrm{ml}$ の当量点付近の状況を観察した．な扔本滴定装置で は当量点付近で出力変化が大きくなると滴定速度が自動 的に遅延するようになっている。

Table 2 に滴定開始から終点までの時間と滴定值を示 すが，3から 17 分まで全体として終点位置が一方にず れる傾向はなく，この沈殿反応は十分迅速に進むものと 考えられる．滴定速度に対する設定としては $0.2 \mathrm{ml} /$ $\min$ とし，これで $1 \sim 0.5 \mathrm{mg}$ の試料中の硫黄は数分以内 に滴定が終了できる.

\section{$3 \cdot 4$ 硫酸イオン量と滴定値の回帰分析}

過塩素酸バリウムは化学式どおりの純品と言えないの で，それを滴定液としたときの濃度係数は硫酸イオンの 
既知量を滴定して決めなければならない。市販の 0.005 $\mathrm{mol} / \mathrm{l}$ 硫酸標準液を用いても良いが, この場合は硫酸標 準液の製造元のはかりと試料を量るはかりとの間で質量 基準が複合するので, 両者の統一が問題である. 一方硫 酸ヒドラジン $\mathrm{H}_{2} \mathrm{NNH}_{2}: \mathrm{H}_{2} \mathrm{SO}_{4}$ が吸湿性でなく, かつ純 度の高いものが得られるので, 電子微量化学はかりで精 密に採取し, 硫酸イオン量の標準とすることができる. そこで硫酸ヒドラジン $1.2 \sim 0.2 \mathrm{mg}$ を計量し, $5 \mathrm{ml}$ の水 に溶解して更に 2-プロパノール $35 \mathrm{ml}$ を加え, 過塩素酸 バリウム液で滴定した.

硫酸ヒドラジンの量と滴定值の関係については Table 3 の数值が得られ, デー夕数 12 について回帰分析を行 った. まず硫酸ヒドラジン中の硫黄量 $x \mathrm{mg}$ に対する滴 定値 $y \mathrm{ml}$ について直線回帰をすると, 硫黄量を真值と 仮定して,

$$
y=6.641 x+0.0237
$$

の回帰式が得られた.

式（1）の切片 $+0.0237 \mathrm{ml}$ は空試験值に相当するが, 本封管燃焼法では試料以外の硫黄源が考えられないの で, この值は滴定装置の終点決定における機構上の理由 と思われる.この空試験値は当然ばらつきを持っている
と考えられるので, 概算值として $0.020 \mathrm{ml}$ を設定した。 いずれにしてもこの空試験值を滴定值から差し引けばほ ほ原点を通る検量線が得られるので, 滴定液の係数はこ の補正した滴定值で求めることとした.

又, 回帰直線からの滴定値のばらつきは偏差平方和と して,

$$
\sum\left(y-y^{*}\right)^{2}=153.08 \times 10^{-6}
$$

が得られる. 但し $y^{*}$ は回帰直線上の $y$ の值である. 式 （2）から不偏分散平方根を求めると ${ }^{11)}$,

$$
\sqrt{153.08 \times 10^{-6} /(12-2)}=0.0039(\mathrm{ml})
$$

となった.

一方 $0.005 \mathrm{~mol} / 1\left[\mathrm{Ba}^{2+}\right]$ の $1 \mathrm{ml}$ は $0.160 \mathrm{mg}$ の硫黄に 相当するから, 式 (3) で表される滴定值のばらつき $0.0039 \mathrm{ml}$ は硫黄の量として $0.000625 \mathrm{mg}$ に相当する. 試料量を $1 \mathrm{mg}$ 量り取ったとすると分析誤差は $0.062 \%$, $0.5 \mathrm{mg}$ に対しては $0.12 \%$ となるので, $1 \sim 0.5 \mathrm{mg}$ の試 料量の分析には十分良い精度での定量が可能である. 更 に微量化学はかりと滴定装置の精密度が向上すれば 0.5 $\mathrm{mg}$ 以下の超微量分析にも有効に利用できると考えられ

Table 4 Representative analytical results of organic sulfur

\begin{tabular}{lcccrr}
\hline \multicolumn{1}{c}{ Sample } & $\begin{array}{c}\text { Weight/ } \\
\mathrm{mg}\end{array}$ & $\begin{array}{c}0.005 \mathrm{~mol} \mathrm{l}^{-1}\left[\mathrm{Ba}^{2+}\right]^{\mathrm{a})} / \\
\mathrm{ml}^{\mathrm{b})}\end{array}$ & $\begin{array}{c}\text { Sulfur/ } \\
\mathrm{mg}\end{array}$ & $\begin{array}{c}\text { Result, } \\
\%\end{array}$ & $\begin{array}{c}\text { Dev., } \\
\%\end{array}$ \\
\hline Diphenylthiourea & 0.7908 & 0.7517 & 0.1097 & 13.87 & -0.17 \\
$(\mathrm{~S}=14.04 \%)$ & 0.6146 & 0.6054 & 0.0877 & 14.28 & 0.24 \\
& 0.8817 & 0.8400 & 0.1229 & 13.94 & -0.10 \\
& 0.9230 & 0.8878 & 0.1301 & 14.09 & 0.05 \\
Sulfanilamide & 0.8077 & 1.0200 & 0.1499 & 18.56 & -0.06 \\
(S=18.62\%) & 0.7924 & 1.0000 & 0.1469 & 18.54 & -0.08 \\
& 0.7458 & 0.9456 & 0.1388 & 18.61 & -0.01 \\
Sulfathiazole & 0.8985 & 1.1325 & 0.1667 & 18.56 & -0.06 \\
(S=25.11\%) & 0.5809 & 0.9964 & 0.1464 & 25.20 & 0.09 \\
& 0.9764 & 1.6585 & 0.2455 & 25.15 & 0.04 \\
S-Benzylthiuronium & 0.7824 & 1.3450 & 0.1986 & 25.39 & 0.28 \\
chloride & 0.8284 & 1.4145 & 0.2090 & 25.23 & 0.12 \\
(S=15.82\%) & 0.9373 & 1.0200 & 0.1498 & 15.99 & 0.17 \\
& 0.8879 & 0.9618 & 0.1412 & 16.90 & 0.08 \\
Thiourea & 0.5050 & 0.5609 & 0.0811 & 0.24 \\
(S=42.12\%) & 0.8622 & 0.9200 & 0.1349 & 15.65 & -0.17 \\
& 0.7622 & 2.1566 & 0.3203 & 42.02 & -0.10 \\
& 0.7660 & 2.1734 & 0.3228 & 42.14 & 0.02 \\
& 0.6319 & 1.8000 & 0.2668 & 42.22 & 0.10
\end{tabular}

a) Factor $=0.9352$ b) A blank value of $0.020 \mathrm{ml}$ was subtracted before calculation of the result. 
る.

\section{$3 \cdot 5$ 分析結果}

ジフェニルチオ尿素, スルファニルアミド, スルファ チアゾールなどについて分析を試みたところ, Table 4 の結果を得た。なお, 滴定液の係数は硫酸ヒドラジンの 単なる水溶液と封管燃焼及び吸収のプロセスを経たもの との間で, 後者のほうが 0.04 前後小さく, その原因に ついては今後の究明が必要であるが, 本実験では硫酸七 ドラジン $1 \mathrm{mg}$ 前後を 2 3 点採取し, 封管燃焼後の滴 定值から係数の平均值を求めた. 分析データとしては一 応満足すべきものであるが，マニュアル操作の多い分析 法であり，更に手法面での合理化や改良の余地が残され ている．なお使用後の封管は原則として廃棄するが，試 料量が少ないときは洗浄後, 長さ $13 \sim 15 \mathrm{~cm}$ の封管を 作って再利用が可能である.

\section{文献}

1）日本分析化学会有機微量分析研究懇談会編：“有
機微量定量分析”, p. 383 (1969), (南江堂).

2) Al Steyermark: "Quantitative Organic Microanalysis”, p.276 (1961), (Academic Press, New York).

3) Pregl-Roth: "Quantitative Organische Mikroanalyse", 7th ed., p.189 (1958), (Springer, Wien).

4) W. Schöniger: Mikrochim. Acta, 1955, 123.

5) E. Pella, B. Colombo: Mikrochim. Acta, 1978 I, 271.

6) 穂積啓一郎, 北村桂介, 田中喜秀: 分析化学 (Bunseki Kagaku), 38, 259 (1989).

7) Y. Tanaka, A. Okazaki, K. Hozumi: Mikrochim. Acta, 1991 III, 169.

8) 穂積啓一郎: 化学の領域, 17, 873 (1963).

9) K. Hozumi, K. Umemoto: Microchem. J., 12, 46 (1967).

10) B. Budesinsky: Anal. Chem., 37, 1159 (1965).

11) 小島次雄: “分析化学に招ける推計学”, 日本分析 化学会編, 基礎分析化学講座 5, p. 117 (1965), (共 立出版).

\section{要 旨}

有機硫黄の微量定量は燃焼管法かフラスコ燃焼法が用いられているが，試料が $1 \mathrm{mg}$ 以下になると精 度維持がしだいに困難になる. 数年前有機ハロゲンの定量に封管燃焼法が提案されここでは閉鎖器中 で少量の純酸素による完全分解と操作中外部からの成分污染や損失が全くない点が評価された。この方 法を有機硫黄の定量に応用しょうとしたが, 八ロゲンのときに用いた外径 $8 \mathrm{~mm}$, 内径 $6 \mathrm{~mm}$, 長さ 15 $\mathrm{cm}$ の封管では酸素が不足で，燃焼ガス中の $\mathrm{SO}_{2}$ をできるだけ $\mathrm{SO}_{3}$ に酸化するためには，外径 $10 \mathrm{~mm}$, 内径 $8 \mathrm{~mm}$, 長さ $18 \mathrm{~cm}$ のものが必要であった. 分解条件としては燃焼温度 $580^{\circ} \mathrm{C}$, 燃焼時間 20 分で 良い，又，封管の針端を吸収液中で破壊して吸収液を導入するが，吸収液には $3 \%$ 過酸化水素水を用い， 10 分で吸収は完了することが分かった。吸収液にはカルボキシアルセナゾを指示薬に加え， 0.005 $\mathrm{mol} / \mathrm{l}$ 過塩素酸バリウム標準液で光度滴定した. 本法は燃焼, 吸収を数点まとめて行えば一日 20〜30 本の分析が可能である. 